
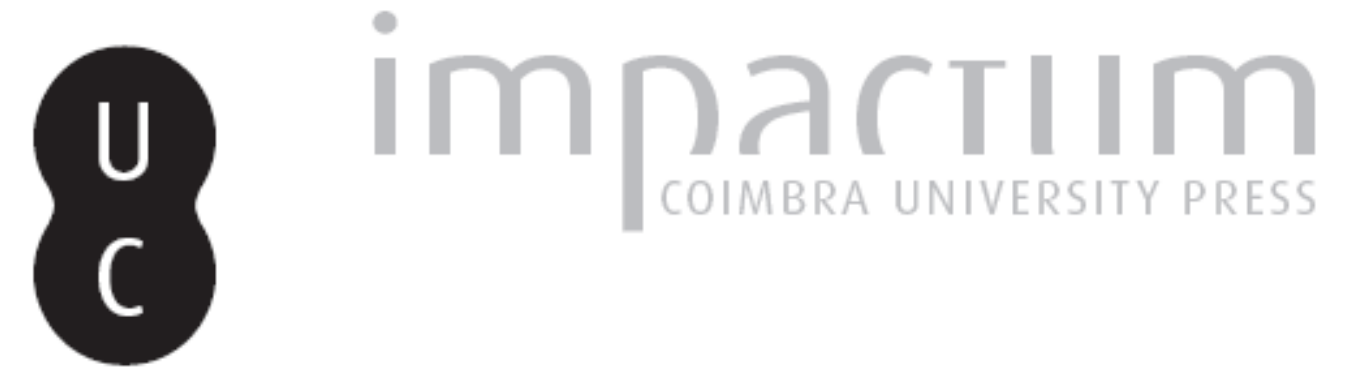

\title{
[Recensão a] Jaime Nogueira Pinto, António de Oliveira Salazar, O Outro Retrato, Revisão e índices de Inês Pinto Basto
}

\author{
Autor(es): $\quad$ Chorão, Luís Bigotte \\ Publicado por: Imprensa da Universidade de Coimbra \\ URL \\ persistente: \\ URI:http://hdl.handle.net/10316.2/36719 \\ DOI: \\ DOI:http://dx.doi.org/10.14195/1647-8622_7_24
}

Accessed : $\quad$ 26-Apr-2023 09:36:38

A navegação consulta e descarregamento dos títulos inseridos nas Bibliotecas Digitais UC Digitalis, UC Pombalina e UC Impactum, pressupõem a aceitação plena e sem reservas dos Termos e Condições de Uso destas Bibliotecas Digitais, disponíveis em https://digitalis.uc.pt/pt-pt/termos.

Conforme exposto nos referidos Termos e Condições de Uso, o descarregamento de títulos de acesso restrito requer uma licença válida de autorização devendo o utilizador aceder ao(s) documento(s) a partir de um endereço de IP da instituição detentora da supramencionada licença.

Ao utilizador é apenas permitido o descarregamento para uso pessoal, pelo que o emprego do(s) título(s) descarregado(s) para outro fim, designadamente comercial, carece de autorização do respetivo autor ou editor da obra.

Na medida em que todas as obras da UC Digitalis se encontram protegidas pelo Código do Direito de Autor e Direitos Conexos e demais legislação aplicável, toda a cópia, parcial ou total, deste documento, nos casos em que é legalmente admitida, deverá conter ou fazer-se acompanhar por este aviso.

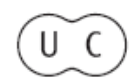




\section{o[s] tempo[s] do[s] medi@}

\section{ESTUDOSDOSÉCULO}

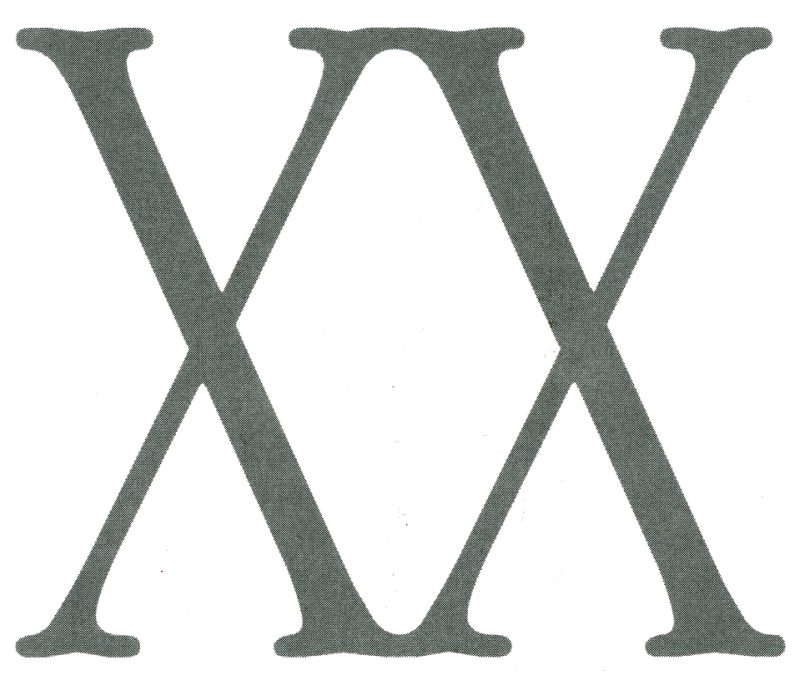

número $7 \cdot 2007$

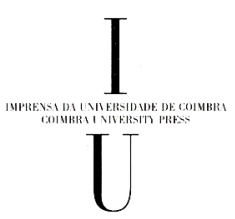


sécs. $X I I I-X X$, Lisboa, Editorial Estampa, 1996); Le Livre Noir du Colonialisme, (traduçáo portuguesa: $O$ Livro Negro do Colonialismo, Rio de Janeiro, Ediouro, 2004).

${ }^{2}$ Courtois, Stéphane et al. - Le Livre Noir du Communisme. Paris, Éditions Robert Laffont, 1997 (tradução portuguesa: O Livro Negro do Comunismo, Lisboa, Quetzal Editores, 1998).

${ }^{3}$ Merle, Marcel - L'Anticolonisme de Las Casas a Karl Maxx. Paris, Librairie Armand Colin, 1969. O Anticolonismo Europeu. Três Séculos de Pensamento Anticolonialista. Lisboa, Iniciativas Editoriais, 1975.

Sérgio Neto

Colaborador do CEIS20

Jaime Nogueira Pinto, António de Oliveira Salazar, O Outro Retrato, Revisão e índices de Inês Pinto Basto, A Esfera dos Livros, 1. ediição, 2007 264 p. +32 de extratexto.

\section{O Outro Retrato ou a Subversão da História?}

Entrado na 3.a edição, António de Oliveira Salazar, O Outro Retrato, da autoria de Jaime Nogueira Pinto (JNP) justifica atenção.

O autor confirmara já talentos por ocasiāo das alegaçôes orais que apresentou na qualidade de defensor de Oliveira Salazar no programa de entretenimento do canal de serviço público de televisão, Os Grandes Portugueses. As alegaçóes escritas foram deixadas por JNP para o Outro Retrato, que a Esfera dos Livros publicou com sentido de oportunidade editorial.
Signatário que fui de um documento legitimamente crítico do formato do referido programa televisivo, que JNP considera ser expressäo ridicuta de reacção a Os Grandes Portugueses, «um abaixoassinado - escreve -, de historiadores "preocupados" ", entendo que seria lastimável deixar passar o momento da divulgaçáo do livro sem que sobre ele, sobre o retrato de Salazar pintado por JNP, se comentasse nada. Merece-o a obra e o autor, mesmo que o registo seja crítico, como o que se segue essencialmente é.

Importará antes de mais clarificar que as observaçóes, notas, interpelaçōes que nos foram sugeridas pela leitura de $O$ Outro Retrato ultrapassam o âmbito limitado da presente recensão, ficando registadas tão só as que nos pareceram mais relevantes, todas se inserindo no domínio estrito do conhecimento historiográfico. É que, se JNP tem todo o direito de escrever sobre Oliveira Salazar o que bem entender, de pintar a personalidade do antigo Presidente do Conselho com as cores que se lhe afiguram quadrarem mais adequadamente à sua visão do. homem e do político, já nos parece criticável que essa visão assente, em aspectos essenciais, numa revisão ou subversão da verdade histórica.

Temos presente que JNP não ilude o leitor e logo lhe propóe uma "visão alternativa", não só do homem, mas do seu tempo, «um relato escrito, uma narrativa breve, corrida, mais de sínteses alternativas do que de problemáticas suspensas" (pág. 15).

A proposta de JNP aparentando resolver um problema, à semelhança do que há muitos anos atrás fizera Jesús Pabón na sua La Revolución Portuguesa', verdadeiramente cria o problema de $O$ Outro Retrato.

Ao contrário de se libertar duma lógica maniqueísta em que à primeira 
vista se enquadraria a sua críica ao que designa por «visão uniforme da historiografia "antifascista"” (pág. 15), JNP acaba traido por essa mesma lógica, atraído, afinal, não pelo retratar, mas pelo retratar de um "outro ângulo". Ora, é exactamente o problema da focagem, que acaba por desvalorizar o livro de JNP enquanto obra historiográfica que não alcança ser, valorizando-o como documento político que na verdade é, e que ficará como testemunho duma "percepçẫo alternativa" na qual se descobre aliás uma linha de coerência assinalável com um texto de juventude do autor publicado na Política em Julho de 1971.

Construído declaradamente $O$ Outro Retrato como "visāo alternativa", cabe perguntar: alternativa a quê, a que visāo ou visóes de Salazar e do Salazarismo? $E$ que, contrariamente ao que pode depreender-se da proposta de JNP, são hoje praticamente inexistentes na historiografia portuguesa visóes ideologicamente comprometidas com qualquer preconceito "antifascista", e a já numerosa produçāo científica sobre o Estado Novo português desmente inteiramente que os investigadores dedicados ao século $\mathrm{XX}$ português continuem apegados aos uclichés" sugeridos por JNP. Pelo contrário, ao que se assiste é ao acolhimento no plano historiográfico de visóes plurais, interdisciplinares, pluridimensionais, que olham o século $\mathrm{XX}$, por imposiçāo de critérios e metodologia científicas, como um tempo histórico, cuja apreensão e compreensão não é por natureza incompatível com o fenómeno subestimado por JNP das "problemáticas suspensas". Essas problemáticas são exactamente as que devem convocar hoje os investigadores, para que as sínteses futuras se possam consolidar em factos, podendo ser verdadeiramente «úteis", e não em (pré) conceitos.
JNP declara-se em condiçóes de «entender o tempo e o homem - o Estado Novo e Salazar - com conhecimento, com substância e com objectividade" e de historicamente o integrar «ultrapassando a "lenda negra antifascista" que permanece entre os seus inimigos, e a cegueira fanática de alguns dos seus simpatizantes» (pág. 14). Tê-lo-á conseguido, ou mesmo visado, numa obra que define como sendo mais de "proposição de problemáticas que de soluçōes definitivas e consolidadas” (pág. 17)?

Sem entrar imediatamente em O Outro Retrato do seu biografado, JNP cuidou de recuar no tempo para traçar de igual modo um outro retrato do Portugal do fim da monarquia e o do Reino dos Democráticos.

Um aspecto sublinhado por JNP é naturalmente a política religiosa da República. Embora refira que o "conflito permanente com a Igreja Católica vai ser uma constante da I República na sua primeira fase» (pág. 36), a verdade é que o autor năo esclarece qual é a "fase" a que faz alusāo, e qual a evoluçâo posterior das relaçóes entre o Estado e a Igreja, como se a política religiosa que decorreu entre 1910 e 1926 se houvesse cristalizado no anti-clericalismo afonsista, esquecendo que a reacção religiosa e político-religiosa na qual acabaria por participar numa linha destacada o próprio Oliveira Salazar, se irá desenvolver já náo contra o Regime, mas "dentro" do Regime, de acordo, aliás, com as directrizes da Santa Sé.

Nos três parágrafos que dedica ao Integralismo Lusitano, JNP escreve que o movimento "começava também por uma revista, Integralismo Lusitano (...)" (pág. 38). $\mathrm{O}$ autor não se detém nem na Alma Pontugueza, nem na Naģăo Portuguesa, títulos que antecederam aquele que cita $\mathrm{e}$ 
se confundem, eles sim, com a fundação do movimento.

Escreve o autor que a "primeira reacção organizada e triunfante, com um pensamento sobre as instituiçôes e vendose como alternativa à República democrática e parlamentar, é o Sem que se pretenda desvalorizar a sidonismo" (pág. 41). importância política da experiência sidonista, é pelo menos duvidosa a afirmação de JNP, tendo em consideração, note-se, o que exactamente sobre aquele "pensamento" haveriam de afirmar colaboradores próximos do "Presidente-Rei", incluindo figuras gradas da política monárquica e do Integralismo Lusitano.

A págs. 45, JNP refere-se a Alfredo da Silva para sublinhar o clima de violência que se vivia no País e levara o "grande industrial" a "viver no estrangeiro". A acção política de Alfredo da Silva constitui por certo uma problemática suspensa, a merecer cuidada investigação, designadamente no que relaciona o seu jornal, Imprensa da Manhä com os acontecimentos trágicos de 19 de Outubro de 1921 , com a "epilepsia da desordem" para utilizarmos as palavras de Raul Proença.

Sobre essa página negra da história contemporânea nacional, faz JNP uma afirmação que pela sua relevância carece de ser demonstrada: a de que era "esquerdista» a "dúzia de marinheiros (...) chefiados pelo cabo Abel Olímpion que no Arsenal liquidaram barbaramente António Granjo. Porquê «esquerdista»? Dispōe porventura o autor de fontes que fundamentem o que afirma, ou trata-se de uma mera convicçáo pessoal? Se assim é, que dados ou informaçốes teve em vista pata a format?

Em relaçāo ao movimento de 18 de Abril de 1925 considera-o JNP uma «mera insurreição moral contra o Partido Democrático...o que não o incomodou ou abalou grandemente", para logo adiante escrever: "Só que os efeitos colaterais do movimento falhado, acabam por preparar o caminho, nas Forças Armadas e no País, para o sucesso futuro" (pág. 46). Pergunta-se entáo: o 18 de Abril abalou, ou não abalou, o poder democrático? A resposta é inequivocamente afirmativa. Abalou, incomodou profundamente. O julgamento do Arsenal e a absolvição dos implicados - reclamada por Oscar Carmona, na qualidade de promotor de justiça -, traduziu-se, como escreveu Raul Proença na consagração do "direito de impunidade"; por isso se disse do 18 de Abril ter sido o "prólogo" do 28 de Maio.

$O$ autor de $O$ Outro Retrato nāo faz mençáo ao gorado movimento de 19 de Julho de 1925 que fo: cheriado por Mendes Cabeçadas, um dos heróis do 5 de Outubro. A desvalorizaçăo desse acontecimento prejudica a compreensão das várias "arrancadas" do 28 de Maio, circunstância em que aquele oficial de marinha se assumiu como uma das faces do movimento, tendo gorado obter, sem derramamento de sangue, a "transferência" de poderes por parte de Bernardino Machado.

O 28 de Maio sintetiza-o o autor, num quadro romanceado e com ténue correspondência com a realidade histórica, escrevendo a dado passo: «Eram $4 \mathrm{da}$ manhā do dia 28 de Maio. Começava a revoluçăo nacional em Braga, capital do Minho e do Portugal católico e conservador do Nortes (pág. 52). O trecho podia ter sido retirado de um manual escolar do Estado Novo, e em certa medida, constitui um passo exemplar do livro de JNP, por corresponder, também ele, a um retrato feito de um outro «ângulo". Uma vez mais, o "ângulo" não favorece o retrato, tanto mais que o autor não esclarece os leitores sobre o que define como "revolução nacional", que supóe logo iniciada a 28 de Maio, quando na reali- 
dade nessa data se inicia apenas um processo de sucessivos golpes de Estado, que se concluirá com a assunção de poderes pelo general Carmona, cuja acção irá permitir que a Ditadura Militar se transforme no momento constituinte do Estado Novo.

$\mathrm{O}$ general Gomes da Costa surge na narrativa como o chefe do movimento, de uma "revolta que alastra, registando progressivas adesóes com as resistências militares centradas quase só nos altos comandos e nos generais politizados" (pág. 54), achando mesmo JNP que quem verdadeiramente mandava e decidia eram os subalternos (pág. 55). Sem que se negue a importância desses militares, a verdade é que a decisão da força armada que fez baquear o governo de António Maria da Silva e encerrou depois as portas do Congresso remetendo para o exílio o Presidente Bernardino Machado, assentou fundamentalmente no compromisso das altas patentes militares e na transaçăa há muito anunciada entre estes e os mais altos responsáveis políticos da República. Se Bernardino Machado acabou por consentir a deposiçáo de poderes em Mendes Cabeçadas - imaginando a viabilidade de uma ditadura comissarial -, o que é facto é que a "marcha sobre Lisboa» acabaria por colocar o movimento em irremediável rota de colisão com as instituiçoes republicanas, tendo-se de imediato comprometido o projecto de uma ditaduma comissarial, que foi substituido na realidade por uma ditadura soberana a qual teve por objectivo destrtivir a Constituição de 1911.

Facto curioso e relevante no discurso de $O$ Ontro Retrato: JNP que insiste na natureza comissarial da Ditadura Militar logo the revela o tipo soberano, ou nâo fosse verdade que o autor regista mesmo a "queda da República» com a entrada do general Gomes da Costa em Lisboa (pág. 55).
Tal como observa o autor, a weuforia unitária do triunfo durou pouco tempon; «entretanto - acrescenta -, o choque deixa uma perda colateral: Salazar, Manuel Rodrigues e Mendes dos Remédios, os professores de Coimbra, perante as confusões entre os militares, declaram não poder permanecer. E explicam que, para eles, a questāo não é técnica mas política não havendo entendimento entre quem manda, os seus serviços de nada poderiam servir. Regressavam, por isso, a Coimbra) (pág. 60). Na verdade, Manuel Rodrigues Júnior optou por permanecer em Lisboa, opção que se iria revelar da maior importância política. Antes de Salazar, e num tempo decisivo, a Ditadura Militar encontrou em Rodrigues náo só $o$ seu político civil, mas também $o$ seu jurista. Em 1946, na Assembleia Nacional, o deputado Joāo do Amaral reconhecê-lo-ia em termos muito expressivos.

A págs. 61 lê-se: “Os democráticos, o sector governante e radical dos republicanos incluindo políticos e militares, receberam com surpresa e perplexidade o 28 de Maion. Com surpresa nấo receberam com certeza. A agitação em certos meios civis e militares era inteiramente conhecida do Governo, designadamente do Ministro da Guerra que conversara em Coimbra com membros do comité revolucionário, reuniāo essa em que participou também o Ministro das Finanças, Armando Marques Guedes que relatou o episódio. O Presidente da República não desconhecia igualmente a situação, só assim se compreendendo as diligências que tomou a iniciariva de realizar, designadamente junto do general Ribeiro de Carvalho, tal como testemunhou seu filho, o ao tempo coronel A.G. Ribeiro de Carvalho, que tinha sido Ministro de Álvaro de Castro e acompanharia de perto Bernardino Machado aquando das "arrancadas" de 28 de Maio. 
Acresce que é equívoca a referência do autor ao sector "radical dos republicanos", tanto mais que estava constituído à época o chamado Partido Republicano Radical, em cujo programa e corpos directivos existia "marca" do outubrismo, partido esse a que - recorde-se -, pertencia o general Gomes da Costa, facto nem sempre referido, mas relevante, desde logo, no currículo político do oficial.

Desconhecendo-se a fonte na qual JNP colheu a informação segundo a qual José Domingues dos Santos, vitoriou na rua o general Gomes da Costa (pág. 61), a verdade é que o jornal da Esquerda Democrática - $A$ Choldra -, revela antipatia e oposiçāo declarada e virulenta do partido ao chefe da "marcha sobre Lisboa", tratando-o nas colunas do jornal com a mais absoluta das desconsiderações.

A afirmação de que o Partido Comunista tinha marcado "com grande sentido de oportunidade» (pág. 61) o seu II Congresso para o dia 29 de Maio de 1926, induz o leitor a concluir que Rates - que anos mais tarde viria a dar a sua adesão ao Estado Novo -, e os seus amigos políticos estavam conhecedores da data das "arrancadas", do que não conhecemos prova. Conhece-a porventura JNP?

Entende o autor que Gomes da Costa foi afastado por "falta de jeito governativo" (pág. 62). Foram porém fortíssimas razōes políticas que estiveram na origem do seu afastamento, insusceptíveis de serem confundidas com mera "falta de jeito». A demissão que provoca do general Carmona traduziu as divisōes profundas que se tinham cavado entre as lideranças das "arrancadas" de Maio, e na origem da qual esteve não só a questáo do regime (sendo que apoiantes de primeiro plano de Gomes da Costa eram partidários da restauração da monarquia), mas, fundamentalmente, o problema da revisão do regime jurídico em que se operava o relacionamento entre o Estado e a Igreja católica. Foi neste quadro que actuou o Ministro da Justiça Manuel Rodrigues Júnior, que chegou a ser dado como demitido do Governo juntamente com Carmona, o qual, no entanto, em poucas horas, seria confirmado como titular da pasta num gabinete presidido exactamente por aquele General, num momento em que Gomes da Costa tinha já sido retirado de cena, primeiro arredado para Cascais e depois embarcado para os Açores.

"Carmona passou a ser o centro geométrico do poder militar" escreve JNP a págs. 62, no que tem razão, afirmação, essa, que de certo modo desmente aquela outra do autor: "Carmona é - será sempre - mais um símbolo do que um líderm. Mas pergunta-se: teria sido possível ao general Carmona transformar-se nesse «centro geométrico", num "ponto de equilíbrio de forças», "apaziguador de conflitos" e "catalizador de energias", num "mediador ponderado e aceite» (pág. 60), mais, na «cabeça hierárquica visível do núcleo militar direitista dos anos 20" (pág. 61), se carecesse de capacidade de liderança? Figura a carecer de estudo aturado, Óscar Carmona não só exerceu como líder, como foi a sua liderança, de facto, assinalada por muitas das características que JNP sublinha, que viabilizou o momento constituinte do Estado Novo em que a Ditadura Militar essencialmente se transformou. Na verdade, só sob a sua liderança foi dado sentido revolucionário à acçáo governativa entăo empreendida. E foi com ele que surgiu, após a derrota "constitucionalista" de Fevereiro de 1927, após o que JNP classifica como a "clarificação trazida pelo 7 de Fevereiro" (pág. 102) a ideia de "Revolução Nacional", tradutora de um plano de convergência de republicanos e monárquicos comprometi- 
dos, antes de mais, na defesa da Siruação c na conquista do Estado, obstaculizando, portanto, com sentido pragmático, qualquer pretensáo de regresso à chamada "normalidade constitucional".

A «agitação interna e externa das oposiçōes» a que alude o autor a págs. 103, teve correspondência com a repressão das suas actividades, que não visou como parece resultar do discurso de JNP, tão só os responsáveis de "manifestaçóes" ou de "atentados bombistas", ou mesmo os implicados na "Revolta das ilhas", mas teve como objectivo desarticular o que ainda restava das antigas organizaçōes partidárias e organizaçôes sindicais e promover - "sancamento" náo apenas do funcionalismo público mas da força armada.

Se as "revoltas de Fevereiro" assentaram naturalmente na máxima mobilização dos sectores oposicionistas à Ditadura Militar, também é certo que as fontes conhecidas não permitem de nenhum modo confundir o sentido político dessas revoltas - que desde logo lhe era dado pela personalidade dos seus líderes militares e civis -, com qualquer plano de "assalto" de "novas forças radicais» (pág. 62) ao poder, ou de risco de bolchevização da República. Da separação de águas, cuidou, aliás, o Partido Comunista que haveria de reconhecer o que considerou um equívoco: a "unidade" com a burguesia em Fevereiro de 1927.

A págs. $68, \mathrm{JNP}$ refere-se, a respeico das «revoltas de Fevereiro», à "violência dos insurrectos». Sem que se negue essa violência, ela não foi exclusiva da acçâo dos «insurrectos". A este propósito merece a pena recordar o testemunho do insuspeito tenente Assis Gonçalves:

"O Ministro da Guerra Passos e Sousa regressara do Porto com a vitória, e na noite do dia 8 os revoltosos retiraram do Rato tendo-se entregado os chefes da revolta às 8 horas do dia seguinte com o seu comandante Mendes dos Reis, no seu Quartel instalado no Hotel Bristol em S. Pedro de Alcântara que fora fortemente batido pela nossa artilharia postada no morro do castelo.

$\mathrm{Na}$ noite da retirada do Rato fui levantar os mortos do tenente Moreira Lopes e levá-los num caminhäo ao mortuário da Estrela. O cenário, no Rato, era de tão fúnebre tragédia, que apetecia estar longe, longe, na Calábria ou entre os cafres do deserto.

Mas, ainda depois, à meia-noite, o comandante Lobo da Costa, supondo que a resistência à sensibilidade não tem limites, me diz: "Vá com uma camioneta armada de metralhadoras percorrer a cidade e fazer cumprir as instruçōes do "estado de sítio", apagar a tiro sinais luminosos, prender ou fuzilar noctívagos $\mathrm{e}$ recalcitrantes se tanto for preciso".

Achei que isto já era de mais e respondi: "Só sei fazer fogo contra inimigos de armas na māo". Compreendeu o melindre, e foi nomeado o tenente Caeiro Cartasco, tảo decidido que nāo tergiversaria em arredar obstáculos. $E$ ao ver preparar a camioneta e montar as metralhadoras, disse ao comandante no momento da saída: "Posso it também como simples observador?". O comandante sorriu, compreendeu e autorizou. Iá fomos percorrer a cidade e regressámos sem ouvir nem dar um tiro". (Assis Gonçalves, Intimidades de Salazar, O Homem e a Sua Época (Memórias do seu Secratário nos primeiros sete e dificeis anos da sua Vida Ptiblica), Lisboa, 1971, págs. 40-41).

Interroga-se o autor: "Como actuou Salazar para, nestes poucos anos, conseguir o poder total no bloco complexo de forças "nacionalistas", ele, que à partida estava, e esteve sempre, sozinho, sem partido, sem lobby?", para concluir que 
foi «com o apoio maciço, definido, definitivo, dos militares» (pág. 81). Conviria esclarecer o tempo histórico desse "apoio", as circunstâncias da sua evolução, por tão marcadamente diferenciado ao longo do Ditadura Militar e do Estado Novo. E recuperar para a narrativa o que se conhece do relacionamento de Salazar com os presidentes dos ministérios que integrou, designadamente com Ivens Ferraz, cujo registo memorialístico constituiu uma fonte de inestimável interesse, até para o conhecimento da personalidade do entáo ministro das Finanças.

Quanto à solidão de Salazar a afirmação de JNP é equíroca. Esteve à partida sozinho ou esteve sempre sozinho? Mas será possível imaginar um homem só com a «apoio maciço" da força armada?

Por outro lado, ainda: sem partido e sem lobby, Salazar não teria sido chamado a formar Governo. Mas se é facto que o Ministro das Finanças acaba por ganhar ascendente político e governativo em relação a outras figuras da Situaçāo, não cremos que possa afirmar-se que antes de 1932 a "verdadeira política» fosse «só com Salazar». A afirmação de JNP parece desconsiderar um conjunto de diversas personalidades cuja acção tornou possível o fenómeno salazarista, entre muitos outros, o já referido Manuel Rodrigues Júnior e Duarte Pacheco. A este último coube, aliás, uma função historicamente assinalável; em primeiro lugar foi Pacheco que se incumbiu de ir buscar Salazar a Coimbra em 1928 e vai ser ele a pedir-lhe, em 1932, que nāo perca tempo - quer dizer, que nāo coloque em risco a indigitaçāo -, e apresente o elenco governativo ao Presidente Carmona. Sobre as circunstâncias em que foi constituído o primeiro governo de Salazar - que se nos afigura contrariarem a ideia de que o presidente do ministério já o era de facto antes de o ser (pág. 103) -, revestem-se da maior importância os registos memorialísticos de Leal Marques, cuja divulgaçāo recente nas páginas da Análise Social se fica a dever a Fátima Patriarca.

A ideia da solidão de Oliveira Salazar, bem como a do seu pessimismo antropológico, ressaltam en diversas páginas de O Outro Retrato, transformada mesmo na chave interpretativa do regime de um bomem só. Assim se explica o discurso de JNP, e os traços que sublinham a personalização do regime, fundado no homem e no seu pensamento político.

O percurso justificativo do autor importa ao exercício de caracterizaçāo da "identidade política do regime que Salazar criou", para traçar as "diferenças significativas" (pág. 98) que o terão separado do fascismo.

Julgando superar o maniqueísmo da discussão, que expressamente denuncia, JNP deixa-se atrair por ele, optando por um discurso legítimo, ideologicamente comprometido, assente nāo no aprofundamento historiográfico das particularidades do salazarismo, mas na dialéctica entre uma concepção apriorística - a do autor sobre o velho problema em discussão, e a que entende ser a partilhada por «alguns círculos, mesmo de açadémicos respeitáveis», que se apresentariam como os mitólogos do antifascismo (pág. 98). É certo que JNP reconhece que na discussão da natureza do regime se atenuaram os "factores maniqueístas" (pág. 99). Ora, se é assim, no que acompanhamos o autor, talvez importe menos ao esclarecimento do problema insistir na crítica dos factores ideológicos que só o têm na verdade confundido, e importe mais apurar a análise historiográfica das realidades concretas. A comparação virá depois, naturalmente, incompatível com pré (juízos), possibilitando, por certo explicar, por exemplo, as motivaçóes que determinaram «o que se encorajou também em Portugal do estilo 
fascista europeu, a nível de propaganda e mobilização de massas” (pág. 121).

A págs. 100 de $O$ Outro Retrato lê-se: "Fica claro que a crítica de Salazar a tal sistema [democrático] e aos seus processos, mais do que uma crítica substancial ou filosófica, é uma avaliação histórica e pragmática de que este regime não funcionou em Portugal, como funcionou, por exemplo, em Inglaterra. E que foi negativo para os interesses nacionais. $E$ que se tivesse-funcionado, pois tanto melhor". Sendo conhecida a avaliação histórica que Oliveira Salazar fez da experiência da I República, expressa em diversos momentos da sua vida política, náo se questionando que essa avaliação tenha sido "pragmática". Porém, já duvidamos que a "crítica" ao sistema democrático de Salazar tenha revestido o carácter que lhe aponta JNP. Atente-se a este respeito no estudo: Centro Católico Português, Princípios e organizą̧äo, Tese apresentada ao $2{ }^{\circ}$ Congresso do Centro Católico Português, 1922, Tipografia da Coimbra Editora, Limitada, Coimbra, 1922, passim. Nele Oliveira Salazar pergunta-se sobre a existência de um direito político cristão, para concluir afirmativamente que a Igreja católica apresentava auma solução própria para os problemas fundamentais do direito politico", escrevendo a dado passo:

"O fundamento do poder público ou origem da soberania que se encontra em Deus (non est potestas nisi a Deo), e que na noçáo cristã exige uma sociedade não igualitária, mas hierarquizada, meio necessário ao homem para a realização dos seus fins. Esta doutrina exclui pois a origem contratual da sociedade e a origem democrática do poder, no sentido de que a origem do poder está no povo e năo em Deus" (ob. cit., pág. 15).

Tal afirmação, perguntamos nós, consentirá que se desvalorize, como o faz
JNP, o carácter substancial, filosófico, da crítica de Salazar ao sistema democrático? Sendo os fundamentos dessa crítica não só filosóficos, mas teológicos, seria de admitir que Salazar se houvesse conformado com o sistema democrático se ele tivesse funcionado entre nós como em Inglaterra? Aqui se entra num domínio meramente opinativo estranho à historiografia. Passemos por isso adiante.

À Constituição de 1933 dedica o autor págs. 104 a 107 . JNP vê na preocupação de "criar legitimação teórica e de deixar articulados para o futuro mecanismos preventivos e regulatórios dos excessos do passado próximo (...) muita da forma mentis de Salazar; e as raizes católicas, bem ao espírito do tempo e da sua formaçãon. Talvez merecesse a pena atentar a respeito da influência de Salazar na redacção do texto constitucional nos estudos que recentemente foram reunidos em livro por António de Araújo ( $A$ Lei de Salazar, Estudos sobre a Constituiçăo Política de 1933, Coimbra, Tenacitas, 2007), particularmente esclarecedores quanto a alguns aspectos da génese do texto constitucional, que confirmando a importância "constituinte" de Salazar, desmentem a ideia de que a Constituição é apenas obra sua, como se antes do seu regresso ao Ministério das Finanças em 1928, não se viesse já discutindo amplamente a reforma constitucional, até com reflexos na imprensa periódica. Só mais tarde o projecto de uma nova Constituição se inscreveu nas finalidades políticas dos sectores preponderantes da Ditadura Militar. Longe de estar só, Salazar esteve muito acompanhado nos trabalhos constituintes, entre outros, pela figura enigmática de Quirino Avelino de Jesus, a que o autor nấo se refere, não obstante a sua proximidade com o biografado. Vigente ao longo de mais de quarenta anos, a experiência da 
Constituição de 1933 impóe que ela seja aprendida na sua dupla dimensão, formal e material. $O$ registo de JNP atenta sobretudo à primeira dessas dimensóes. A realidade constitucional foi porém muito distinta da ideologia constitucional. Faltou em Constituiçáo material o que sobejou em Constituiçăo semântica. Como JNP acaba por reconhecer, houve separaçāo de poderes, mas quem "domina" é o executivo; a Assembleia Nacional era eleita por sufrágio universal e directo, mas "este "universal" não era tâo universal como isson (pág. 106) e a Câmara Corporativa organizada como cum embriāo, verticalista pela sua composiçāo; de uma "organização corporativa"” (pág. 107), nāo passaria disso mesmo - afirmamos nós - transformada que foi, nāo em instrumento de uma «terceira via» como sugere JNP (pág. 107), mas da via única em que acabaria por se cristalizar o regime do Estado Novo.

Caracterizando o modo como Salazar actuava "na gestāo das crises, e mesmo em relaçāo aos seus inimigos ideológicos da Primeira Repúblican, escreve JNP que o método era "nunca os desesperar" e acrescenta: "Quando se tornam demasiadamente incómodos e entram claramente em conspiração e rebeldia, chegará à sua expulsão e fixação de residência nas Ilhas, no Ultramar ou no estrangeiro. Mas tudo é feito geralmente de forma civilizada, como entre os militares das revoluçoos da Primeira República e dos primeiros tempos da Ditadura que, quando vencidos, partem para esses exilios nos seus trajes civis normais, às vezes com os comandantes do lado contrário a despedirem-se no cais, com toda a urbanidade. Por isso, também as revoluçōes se repetiam..." (pág. 110). Há nas linhas transcritas muito de verdade histórica. De facto, o clima de insurreição permanente em que viveu a I República, que subsistiu ao longo da sua vigência e acabaria por estar na origem da sua desgraça resultou em grande medida do clima de impunidade que se instalou no País. Acresce que funcionou como factor agravante desse clima a camaradagem - para o que contribuíra em momento próximo a experiência nas trincheiras da Flandres -, presente na relaçáo entre os militares, militares cuja omnipresença na vida política nacional o autor não deixou de sublinhar (pág. 39). Compreende-se, portanto, que tais factores determinassem modos de procedimento que se afastavam, regra geral, de violências inúteis. Sublinhe-se que ao sucesso militar das "arrancadas" do 28 de Maio não foi estranho aquele factor $\mathrm{da}$ camaradagem, que, em ultima instância, travou o confronto físico. E se é verdade que o mesmo ambiente foi vivido nos primeiros tempos da Ditadura Militar, já os acontecimentos de Fevereiro de 1927 abrem um novo capítulo na história desse tempo, como JNP, aliás, reconhece. Quando Salazar assume funçōes em 1928, e em 1932 é nomeado chefe do Governo, já a Ditadura Militar se assumira como Revoluçáo, identificara os seus adversários e reprimia-os. Ao afirmar que "tudo" era feito "geralmente de forma civilizada", e que Salazar adoptava umétodos de brandos costumes", JNP constitui-se no dever de o demonstrar, com factos e datas.

Não entrando na apreciaçāo detalhada dos Capítulos VII (No Labirinto Espanhol) e Capítulo VIII (Pequeno Pais, Grande Politica: Portugal na II Guerra), nem por isso eles deixaram de merecer a nossa leitura crítica, em especial a versão do autor sobre o encontro de Hendaya entre Hitler e Franco. Na perspectiva de JNP, o «líder espanhol cria intencionalmente, com pedidos materiais e político-territoriais, um condicionalismo difícil e quase 
impossível para Hitler». Mas terá sido «intencionalmente», ou em Hendaya, Franco náo reconheceria sobretudo no seu interlocutor o previsível vencedor $\mathrm{da}$ contenda? E Gibraltar deixou de ser uma prioridade por virtude da política de Franco, ou por motivo da reorientaçáo estratégica e dos planos de guerra do Eixo?

Um outro aspecto justifica a nossa interrogativa: "Salazar estimava, respeitava e confiava em Franco, e Franco pagava-lhe da mesma moeda». A afirmação de JNP é feita no contexto das referências à guerra mundial. Mas terá sido assim, de facto assim? E pergunta-se: se os sentimentos de Oliveira Salazar por Francisco Franco tivessem sido aqueles, não teria sido natural que o presidente do Conselho o tivesse demonstrado publicamente, deslocando-se a Coimbra para a cerimónia de imposição das insígnias doutorais ao Generalíssimo? Ainda para mais num acto carregado de significado político, pela justificação jurídica e moral que aí foi ensaiada do Alzamiento e da Cruzada nacionalista? E ainda: esses sentimentos a terem existido mantiveram-se ao longo da duradoura relação entre os ditadores peninsulares?

A págs. 143 escreve JNP: "Os comunistas, por sua vez, estavam interessados no frentismo, desde que fossem eles a mandar. Quando isto não acontecia, como na campanha do general Norton de Matos à presidência da República, entravam em ruptura violenta com os seus aliados. O velho general, grande defensor do império ultramarino, acabou mesmo protegido pelo Governo da vingança dos comunistas. E, no final, o PCP sempre arranjava forma de boicotar as eleiçōes, levando a oposiçáo a desistir, alegando falta de garantias". As desinteligências do PCP com Norton de Matos, que se relacionaram com a desistência da sua candidatura continuam envoltas em mistério.
Se é facto que os comunistas defenderam junto do General a tese de qque não estavam reunidas condiçóes para o levar a votos, a verdade é que, também de diversas figuras responsáveis pelas estruturas locais da candidatura, sem qualquer ligação ao PCP, chegaram indicaçōes no sentido da desistência. Que Norton de Matos se transformou num apologista da máxima unidade da oposiçāo, mas com exclusão dos comunistas, é também verdade, mas que tenha passado a estar "protegido pelo Governo da vingança dos comunistas» é um dado novo, cuja fonte importaria que fosse revelada por JNP. Facto assinalável, JNP menciona em 1951 (pág. 142) o nome de Quintão Meireles sem aludir ao de Ruy Luís Gomes -, ficando por lembrar que Meireles fora Ministro da Ditadura Militar e se apresentou como candidato apoiado por figuras, algumas das quais haviam desempenhado um papel de primeiro plano na Situação saída das "arrancadas" de 1926, apresentando a sua candidatura contra a perversáo do "programa" do 28 de Maio.

JNP regressa a pág. 144 aos números de Uma economia a crescer, para a dado momento da narrativa, reconhecer que "só» quanto à mortalidade infantil os números nacionais eram usignificativamente acima da média (65/1000 em Portugal para $31 / 1000$ na Europa - EUA nos anos 60 s e "que se poderia ter feito mais" para combater o analfabetismo (pág. 145). En matéria de resultados económicos, talvez mereça a pena contrastar o quadro de JNP com os números de Silva Lopes na obra já antes citada, olhando designadamente para o Indice de Desenvolvimento Humano (IHD) (aut. cit., $A$ economia portuguesa no século $X X$, Imprensa de Ciências Sociais, págs. 53-56).

De acordo com JNP, os "grandes escritores, que publicavam livremente - Aquilino 
Ribeiro, Ferreira de Castro, Miguel Torga, Virgílio Ferreira, os neo-realistas todos, Cardoso Pires, Manuel da Fonseca, Alves Redol, Urbano Tavares Rodrigues, assim como os principais poetas e críticos literários, eram contra o Regime» (pág. 155). Tal informação não tem correspondência com a realidade histórica. Aliás, todos os autores cujo nome é expressamente citado pelo autor foram vítimas da censura, as suas obras apreendidas, autorizadas com cortes, ou òbjecto de proibição de reediçōes. Estes são os factos.

Uma história pitoresca (págs. 167-168) - como outras que ilustram a narrativa -, leva o autor a consagrar Oliveira Salazar como: O Provedor de Justiça, sublinhando, na oportunidade, o carácter "atento e humano" do Presidente do Conselho. O episódio relatado revela, porém duas realidades. Em primeiro lugar a importância de certas figuras ou interesses, só aparentemente colocadas à margem pelo poder político, mas na verdade influentes e poderasas, e, em segundo lugar, a intromissão directa de Salazar em assunto da alçada do judicial. Nenhuma razáo havendo para duvidar da história, regista-se o seu significado político, interessante para a compreensão da forma como em muitos momentos foi entendida a separação de poderes durante - Salazarismo, tanto mais que, como o próprio autor escreve, as autoridades respeitavam os «santuários sociais» (pág. 171).

Nas páginas que dedica à upedra oscilante», ou seja à Igreja católica nos anos 50 e 60 (págs. 168-171), JNP não escapa também à lógica dos contrastes - para evitar chamar-the maniqueísta -, entre a «Igreja de Pio XII, do Cardeal Cerejeira, conservadora, constantiniana, devota, com a memória da Primeira República, grata a Salazar", que no dizer do autor "vai progressivamente perder terreno» e aquela outra Igreja, a de João XXIII e Paulo VI.
Por este último Oliveira Salazar não escondeu a antipatia pessoal, exacerbada pela viagem papal a Bombaim, e em geral, pelo entendimento da Santa Sé do problema colonial português. As confidências que Franco Nogueira revelou, são muito significativas quanto à perspectiva de Salazar $\mathrm{cm}$ relação à política do Vaticano, subjazendo a ela, afinal, a incompreensão do Presidente do Conselho com a realidade do Concílio Vaticano II, tema que JNP nâo aborda, preferindo antes a alusáo a acontecimentos domésticos que sendo historicamente relevantes, não explicam o facto essencial: a ruptura de Salazar com a Igreja conciliar. E nessa ruptura se espelha, também, o pessimismo antropológico de Salazar e a dificuldade que revelou em entender que os fenómenos evolutivos não têm por consequência inevitável liquidar as instituiçóes, antes podem revelar-se poderosos motivos do seu engrandecimento por via da renovaçáo e da modernidade.

O autor é da opiniāo que Salazar recrutava os seus ministros unuma linha de competência funcional e não de experiência ou competência políticas", fornecendo depois uma lista de nomes que o comprovaria (pág.173). Limitamo-nos a registar a nossa divergência no que respeita à generalização implíçita na afirmação do autor, e se concedemos quanto à "experiência" - já que são inúmeros os casos de recrutamento político entre jovens para o exercício de altas funçōes de governo -, já não aceitamos que Salazar desvalorizasse o factor da competência política dos seus ministros, tanto mais que é conhecido o, por regra, moroso processo de escolha, e a audição prévia a que procedia junto de figuras da sua confiança sobre o nome ou nomes possíveis para o desempenho dessas funçōes.

Declara o autor, a respeito dos «escalóes médios e superiores" da administra- 
çăo pública durante o Estado Novo, a "neutralidade ideológica" dos funcionários, justificando-a no "recrutamento", para o qual nảo se lhes «reclamava uma participaçáo e fidelidade ideológicas à UN, mas competência e lealdade funcional" (pág. 174). Sem entrarmos em detalhes que a importância do tema do funcionalismo público durante o salazarismo inreiramente justifica, incompativel no entanto com o objectivo da presente recensão, sempre se lembrará a vinculação dos servidores do Estado a uma declaraçáo de honra de carácter político, cuja natureza, conteúdo e objectivos, contraria a afirmação genérica de JNP.

A identificaçáo do autor com as directrizes de política ultramarina de Salazar, protagonizada nos anos finais do seu consulado pelo Ministro Alberto Franco Nogueira, influencia naturalmente a narrativa que JNP intitula significativamente: $A$ Última Batalha (págs. $184 \mathrm{e}$ sgs.). Apenas duas observaçōes. A primeira para notar que se é verdade que a I República não discutiu a dimensão colonial do País, antes pelo contrário, nunca compreendeu a realidade nacional senão na sua dimensão pluricontinental, já é duvidoso que possa afirmar-se, como o faz JNP, que Salazar integrou o "patriotismo ultramarinista da Primeira República". É que outros, que não Salazar, podiam ser testemunhos desse "patriotismo ultramarinistan, os quais sem quebra de princípios, haviam compreendido que o tempo mudara e encaravam crítica mas construtivamente a política ultramarina, como o fizeram os subscricores do Programa para a Democratização da República, em Janeiro de 1961, ao acentuarem a "reprovaçáo de processos internacionalmente condenados", e ponderando:

"Problema essencialmente político como este é, torna-se forçoso reencontrar na paz - nunca na guerra - o caminho do diálogo entre as populaçōes e o asseguramento de todos os direitosn.

A segunda observação é relativa à afirmação do autor (pág. 198), segundo a qual "a opinião pública $e$ as famílias tinham-se adaptado, talyez sem entusiasmo, mas também sem tragédia, a uma ideia de conflito de longa duração, que tinha como contrapartida manter o Ultramat». O domínio é o da mera convicçāo do autor, mas que factos, que dados sociológicos, que inquérito, o habilitaram a formar tal conviç̧ão?

Para um capítulo final de $O$ Outro Retrato, JNP deixou a Repressão: o outro lado do espelho. A seu respeito três nótulas críticas. A primeira de carácter geral. JNP náo inclui, e na sistemática da sua obra talvez fosse este o capítulo indicado para o fazer, uma reflexäo sobre o funcionamento dos tribunais, designadamente dos tribunais políticos, da condição prisional dos condenados por sentenças judiciais ou por mera aplicação ou prorrogaçăo de medidas de segurança, da náo admissão ou demissáo do funcionalismo público por motivos de opiniāo, da actuação da polícia política mais conhecida agora a partir da recente investigação de Isabel Flunser Pimentel, da actuação da censura nos domínios da imprensa, do livro, do cinema e do teatro etc. Isto é, há aspectos essenciais da repressão, que nẩo era apenas "reactiva" como afirma o autor (pág. 206), os quais náo são abordados.

Segunda nótula. Na pág. 208, escreve JNP: "A Ditadura Militar, como ditadura comissarial, instituiu uma Censura ad hoc, pensando aboli-la rapidamente». Nāo voltamos aqui à crítica já assinalada à classificação da Ditadura Militar proposta pelo autor, mas a um aspecto da história da Censura. Em que fundamento se apoia o autor para escrever que "era" intenção 
da Ditadura Militar «aboli-la rapidamenten?

Terceira nótula, muito breve. Escreve JNP, sobre o assassinato de Humberto Delgado: «É pouco credível a tese de que Salazar ordenasse a sua morte ou consentisse numa operação para matar Delgado" (pág. 212), afirmando logo na página seguinte: «Conclusão: a PIDE matou Delgado sem conhecimento prévio e muito menos sob ordem de Salazar» e na pág. 214: "Crime ou erro, o caso Delgado ficará como uma outra sombra negra no regime (...)». Em que ficamos?

Um Juizo no Final podia igualmente ter sido incluído a título de prólogo: Um Juízo no Princípio. É a justificação do discurso ideológico, da anunciada "visão alternativa", em síntese $O$ Outro Retrato. Pena que JNP não tenha reflectido na frase dita por Salazar a Franco Nogueira, registada por este no seu Diário a 15 de Julho de 1963: "Nunca se deve ser ministro durante trinta anos. Aprende-se muito, assiste-se a muita intriga, a muita reviravolta, a muita desonestidade. Fica-se com uma ideia horrorosa da humanidade. Horrorosa!».
1 Numa nota preambular dedicada aos leitores portugueses, escreveu Jesús Pabón, La Revolución Portuguesa (De Don Carlos a Sidónio Paes), Vol. I, Madrid, Espasa - Calpe, S.A., 1941, pág. 7: “En primer lugar, mi libro no es imparcial. Es decir, toma partido por Don Carlos conta Alfonso Costa, por Sidónio Paes contra Bernardino Machado; en definitiva, por el Estado Nuevo contra el régimen demoliberal" (existe tradução portuguesa).
Luís Bigotte Chorão

Colaborador do CEIS20 